\title{
Permaculture demonstration sites in Central America: contributions to agroecological transition and implications for educators
}

\section{Sitios de demostración de permacultura en la América Central: contribuciones a la transición agroecológico e implicaciones para educadores}

\author{
Brian W. Conz ${ }^{1}$ \\ Westfield State University, \\ Estados Unidos de América
}

\begin{abstract}
Central America has been an important region for the agroecological revolution, building on a history of intensive smallholder farming practices, farmer-to-farmer knowledge sharing and agrarian social movements. Permaculture is an approach to ecological site design and agroecological transition, which has grown in popularity in Central America in recent years. Permaculture's entrance into the larger movement for agroecology in Central America raises some important questions. How does permaculture intersect with these existing forces? How can permaculturalists address perceptions that it is yet another colonialist development intervention by well-meaning Northerners? What are the implications for educators who visit permaculture demonstration sites with students? In order to explore these questions and to contribute to discussions regarding permaculture's contribution to agroecological transition in Central America I visited two permaculture demonstration sites and participated in site tours. I discussed site features with farmers and gathered information from farm websites. I bring these experiences into conversation with the academic literature on agroecology and permaculture. I conclude that permaculture sites make valuable contributions to agroecological transition in Central America. I also identify important risks that sustainability
\end{abstract}

1 PhD, Associate Professor, Department of Geography, Planning and Sustainability, Westfield State University, 577 Western Ave., Westfield, MA 01086-1630. bconz@westfield.ma.edu

Este artículo corresponde a la ponencia presentada en el 35th Conference of Latin American Geographers realizada en San José, Costa Rica del 20 al 22 de mayo del 2018. 
educators using permaculture demonstrations sites should be aware of and I offer suggestions for addressing these risks.

Keywords: Agroecology, permaculture, Central America, sustainability.

\begin{abstract}
Resumen
Centroamérica es una región importante en la llamada revolución agroecológica, brotando de una historia de prácticas intensivas de campesinos, campesino-a-campesino diálogos, y movimientos sociales agrarias. Permacultura es un acercamiento al diseño ecológico de sitios y transición agroecológica, lo cual ha ganado popularidad en años recientes. De la entrada de la permacultura al movimiento para agroecología más grande surgen unas preguntas importantes. Como caracteriza el encuentro entre permacultura y estas fuerzas ya existentes? Como enfrentan los permaculturalistas las percepciones de que la permacultura es otra forma de desarrollo colonialista por extranjeros del norte? Cuales son las implicaciones para educadores que visitan sitios de demostración de permacultura con estudiantes? Para explorar estas temas y contribuir a las discusiones de la contribución que hace permacultura a la transición agroecológica visite a dos sitios de demostración de permacultura en Centroamérica y participé en giras de los terrenos y conversaciones con agricultores. Integro estas experiencias con la literatura académica sobre agroecología y permacultura. Concluyo que la permacultura esta hacienda Fuertes contribuciones a la transición agroecológica en Centroamérica. Al mismo tiempo, identifico algunos riesgos para educadores que usan sitios permaculturales e identifico paso para mitigar estos riesgos.
\end{abstract}

Palabras clave: Agroecología, permacultura, Centroamérica, sostenibilidad

\title{
Introduction
}

Within the movement for sustainable agricultural development and food sovereignty transitioning to agroecological production has been seen as the key strategy for mitigating the impacts of climate change and the erosion of ecological and cultural resilience, providing a context for experimentation, and deep engagements with local environments and traditions of agricultural resource management (Altieri and Toledo, 2011; FAO, 2014; Edelman et. Al. 2014; Holt-Gimenez and Altieri, 2013). Permaculture is an approach to achieving the transition to agroecology that employs a series of design principles that aid resource users in the elaboration of closed-loop food production and resource conservation systems (Ferguson and Lovell, 2014). The permaculture concept is closely associated with Australian ecologists Bill Mollison and David Holmgren (Holmgren and Mollison, 1978; Mollison, 1988; Holmgren, 2002) but has been expanded and built upon by practitioners around the world, including in Central America, where a number of permaculture demonstration sites have been developed. Permaculture's entrance into the broader movements for 
Brian W. Conz. Permaculture demonstration sites in Central America: contributions to agroecological transition and implications for educators

food sovereignty, agroecology, indigenous and small holder resistance in Central America (and elsewhere in Latin America) raises some interesting questions. In a region with such a vibrant tradition of agroecological activism and experimentation, how does permaculture intersect with these larger movements? How can (mostly) Northern permaculturalists make valuable contributions to the agroecology movement without imposing Western science and solutions on others? What are the implications for sustainability educators bringing students to permaculture demonstrations sites in Central America?

\section{Methodology}

In order to address these questions and to contribute to the discussion of agroecology in Central America I draw on several years of personal experience with Central American smallholders, principally in Guatemala and Belize, and recent visits to two permaculture demonstration sites in each of these countries. At each of these sites I participated in farm tours and question and answer sessions with the farmers and other tour participants. I also draw from the information about each of the sites available on their websites. This information is complemented by my own experiences in Permaculture Design Certification (PDC) courses and other permaculture courses, which I have participated in as a student and instructor. I bring these experiences into conversation with the literature on agroecology in Central America as well as the growing body of academic literature on the specific application of permaculture in the context of the Global South, and Central America in particular.

\section{Regional Context}

Central America has a long history of agrarian struggles against the dislocations and predations of industrial and export oriented agriculture. During the 1960s the region became a proving ground for green revolution technologies and market-led rural development strategies while alternatives based on historically robust agricultural resource management traditions (Wilken, 1987) became further marginalized, and in some cases, were violently targeted for the supposed threat they posed to large land-holding elites (Holt-Gimenez, 2006 p. 5-8). Following the intense civil conflicts of the 1980s a movement for sustainable agricultural development emerged, 
shored up by the growth of grassroots organizing around peasant and indigenous rights, and environmental awareness, and building on traditional farmer knowledge and the experiences of farmer-to-farmer organizers and extensionists of the 1970s and 1980s (Holt-Gimenez 2006). This movement has crystalized around agroecological practices, horizontal knowledge sharing and creation, and international resistance to the displacement of small-holders, the destruction of local and regional food cultures and farming (Altieri and Toledo, 2011; Rosset and Martinez-Torres, 2012). The modest gains of this nascent movement in Central America were brought into sharp focus in 1998, when, in the aftermath of hurricane Mitch, the differences between the vulnerability and resilience of agroecological versus conventional green revolution technology dependent agriculture were measured, boosting the credibility of agroecology in the region (Holt-Gimenez 2006).

\section{Theoretical and Conceptual Framework: Agroecology and Permaculture}

Miguel Altieri (2002) described the technical scientific component of agroecology as 'the application of ecological science to the study, design and management of sustainable agroecosystems' (quoted in Altieri and Toledo 2011, p. 588). Taking their inspiration from traditional agricultural practices, agroecologists have elaborated a research program in support of smallholder resilience and continued innovation (Altieri, 1995; Altieri and Nichols, 2017; Bunch 1999). The still growing body of scholarship documents agroecology's success in creating highly productive farms that protect ecosystem services and buffer farmers from the debt-laden, capital intensive and dependent relationships that characterize green revolution programs (Holt-Gimenez and Patel, 2009). Agroecologists work with agro-ecosystems in order to increase the 'diversity and complexity of farming systems via polycultures, rotations, agroforestry, use of native seeds and native breeds of livestock, encouraging natural enemies of pests, and using composts and green manure to enhance soil organic matter' (Altieri and Toledo, p. 588).

The forms of social engagement and pedagogical approach of agroecology have followed the progressive approaches of the farmer-to-farmer tradition and the critical pedagogy of Popular Education articulated by Brazilian educator Paulo Friere (Bunch and Scarborough, 1996; Holt-Gimenez 
Brian W. Conz. Permaculture demonstration sites in Central America: contributions to agroecological transition and implications for educators

2006; Rosset, et. Al. 2011). In practice then, agroecology 'is based on techniques that are not delivered top-down but developed on the basis of farmers' knowledge and experimentation... [and] emphasize the capabilities of local communities to experiment, evaluate and scale-up innovations through farmer-to-farmer research and grassroots extension approaches' (Altieri and Toledo, 2011 p. 588-589).

Permaculture is an approach to ecological design which can be seen in the broader context of these efforts toward agroecological transition and community and farmer empowerment (Ferguson and Lovell, 2013). In recent years geographers and anthropologists have begun to pay greater attention to permaculture, especially for its contributions to the larger projects of food sovereignty, agroecological transition, climate friendly agriculture and sustainability (Caradonna and Appfel-Marglin, 2017; Lockeyer and Veteto, 2013; Millner, 2016, 2017; Trauger, 2017).

The ecological approach of permaculture is integrated into a series of ethical positions summarized in the three tenets of care for Earth, care for people and fair distribution of surplus (Holmgren, 2002 p.1) emphasizing, as Trauger states, a high degree of integrativeness between nature and society (2017, p. 44). There is a strong emphasis on community-based approaches, community building activities and processes and permaculture has been very strongly linked to the development of eco-villages and transition towns (Taylor Aiken, 2017; Trauger 2017). Permaculture often employs progressive educational approaches, which are best represented in the Permaculture Design Certification course, or PDC. These intensive courses are typically 72 hours in length and involve a mash-up of horticultural skills, ecological site design and critical education around the environmental crisis and social justice topics.

Each PDC involves an ecological site design project, a collaborative process whereby participants work in teams to conduct a comprehensive site analysis, examining climate, micro-climate, landform, soils, hydrology, drainage, vegetation, wildlife, paths and ways. Student practitioners are then encouraged to 'work from patterns to details' (Holmgren 2002), creating design maps that identify patterns of energy, material and nutrient flows before introducing individual design details. Considerable attention is typically given to the setting of goals for a given site as well as the local social and community contexts that will likely influence future outcomes. 
The successful application of permaculture principles to achieve productive agroecologies that support biodiversity and ecosystem services is illustrated in demonstration sites around the world. As Ferguson and Lovell (2013) have convincingly argued, many of the core features of permaculture site design, which include 'perennial polyculture, water management and the importance of agroecosystem configuration exceed what is documented in the scientific literature' on agroecology (p. 251, my emphasis). On the surface then, permaculture provides a highly effective set of approaches within the broader movement for food sovereignty and agroecological transition in Central America. However, given the long history of agrarian struggles and agroecological activism in the region, we must ask, what is different about permaculture, and how does it intersect with these existing traditions and efforts? Additionally, we must engage with some of the critiques that have been leveled at permaculture from the perspective of postcolonial and indigenous theorists. A look at the work taking place at demonstration sites helps to provide further context for these discussions.

\section{Atitlan Organics: A Diversified Permaculture Farm in Highland} Guatemala

Lake Atitlan is a massive caldera lake, ringed by strata volcanoes Maya Indian villages in the Guatemalan highlands with a history of traditional intensive land use and conservation practices (Mathewson, 1984). It is also the site of one of the oldest permaculture centers in Central America, the Instituto Mesoamericana de Permacultura, or IMAP. Founded in the early 2000s, IMAP has hosted numerous PDCs and has served as a permaculture demonstration site and seed-saving venture. According to its website, IMAP includes an 'ecological education center to promote permaculture techniques, local biodiversity, production of organic food, and a seedbank that strives to reconstruct Maya seed heritage' (IMAP, 2018). IMAP has helped to connect contemporary environmental concerns of the Maya with the international enthusiasm for permaculture.

Growing in part out of a relationship with IMAP, Atitlan Organics is a 2.2-acre farm employing permaculture design techniques and strategies for commercial and subsistence production. The farm serves as a permaculture demonstration site where intensive and regenerative farming practices have transformed a degraded rocky hillside into 'an interwoven

116 Revista Geográfica de América Central No 61E (3) Especial CLAG Este artículo está bajo una licencia e-ISSN 2215-2563 • Julio-diciembre 2018 • pp. 111-124 Doi: http://dx.doi.org/10.15359/rgac.61-3.6 
Brian W. Conz. Permaculture demonstration sites in Central America: contributions to agroecological transition and implications for educators

patchwork designed to capture water, soil, sun and other valuable resources while also producing high value products for sale and trade' (www. atitlanorganics.com). The farm supplies income and food for three families, and is self-sufficient in terms of costs/inputs and farm income/outputs (Qudsi, personal communication).

As a permaculture demonstration site, Atitlan Organics illustrates the effectiveness of core permaculture and agroecological principals and strategies. In fewer than 10 years, the designers have developed three key land-use types: food and fuel forest (20\% of the site), intensive vegetable cultivation (30\%) and food forest with integrated wetlands (50\%) (www. atitlanorganics.com). Typical of permaculture sites, Atitlan Organics uses a predominance of tree crops, which are both highly productive while providing an abundance of other 'stacked' functions (biodiversity, rainfall interception and soil protection, fuel and fiber, etc.). The farm is further divided into more than a dozen strategically located and timed paddocks for rotating harvest, livestock and planting activities. Through experimentation the farm has attempted to fine tune an appropriate diet keyed to the productive and regenerative capacity of the site, landing on a robust variety of intercropped staples including avocado, tree tomato (Cyphomandra spp.), sweet potato, taro (grown in micro-wetlands), plantain, turmeric, lime and the cucurbit guisquil, among others. Among the avocados the farm grows is a local landrace the farmers are working to protect and propagate.

Atitlan Organics was started by a couple from the northeast of the U.S. and is part of a series of projects emerging around permaculture in the lakeside town of Tzununa, including a guest-house catering to international tourists, and educational programing including PDC courses and natural building workshops. Atitlan Organics collaborates with other farms and businesses employing permaculture strategies to offer PDCs and Advanced PDCs. These include a consulting group which works internationally and is focused on natural building with materials such as cob/adobe and bamboo, an organic farm in Antigua, a commercial agroforestry operation and chocolate producer in the Sierra de las Minas (www.atitlanorganics.com). IMAP and the community of Quixaya, both Maya-led organizations (in contrast to the organizations listed above) are also engaged in collaborations with Atitlan Organics (Qudsi, personal communication). The collaboration with Quixaya is especially noteworthy, since it has been one of the 
great success stories of agroecological implementation in Guatemala, due in large part to the activism of the grassroots Peasant Committee of the Highlands (Copeland, 2018). Based on this list of activities, the evidence of cooperative work within the community of Tzununa, and the apparent success of the farm itself, it appears that Atitlan Organics is emerging as a potent force for agroecological transition and activism in the area.

\section{Maya Mountain Research Farm: Permaculture Demonstration in Toledo District, Belize}

Maya Mountain Research Farm (MMRF) is a demonstration site developed on a former citrus orchard on the Columbia River in Southern Belize. This 25-acre site has been farmed since 1991 with the goal of permaculture inspired agroforestry development and other intensive cultivation practices. MMRF has experimented with a broad range of useful neotropical and pantropical plant species and implemented planned forest succession based on local analogues and experiences in order to create, in the words of the farm director, 'an education and training center for the idea that we could convey information by walking through a three-dimensional model of a working agroecology system... [showing] active models of permaculture thought and food forest' (mmrf.bz.org). Canopy trees are a mix of nutritious food and timber species with an understory of cacao (including local landraces), papaya, Musa, palms and some citrus. Pineapple, taro and cassava cover extensive areas of ground, often in hedge rows and patches. Other types of cultivation include Inga alley cropping, some intensive annual horticulture, and some livestock, mostly chickens at the time of the site visit. Structures on the site were built using natural building techniques such as timber framing and wood clapboards milled on site, locally available stone, cob and bamboo. The farm's slogan is Food Security Through Biodiversity and in 2016 a University-run bird count found over 151 species on the farm in a 10-day period. Other experimentation at MMRF includes the production and application of biochar as a soil amendment, the implementation of off-grid photovoltaic solar power systems and human waste composting systems.

MMRF has been able to pull together diverse groups in their annual PDC courses including members of Garifuna and Maya communities, national and international NGOs, student groups and other enthusiasts. The

118 Revista Geográfica de América Central No 61E (3) Especial CLAG e-ISSN 2215-2563 • Julio-diciembre 2018 • pp. 111-124 Doi: http://dx.doi.org/10.15359/rgac.61-3.6 
Brian W. Conz. Permaculture demonstration sites in Central America: contributions to agroecological transition and implications for educators

farm has a stated interest in social equity work, and they offer workshops for local women's groups and schools. These include activities for the creation and marketing of value-added products such as jams, vinegar and wine. The farm has also helped to spearhead a vanilla bean industry in the area, working with local farmers to create the Organic Vanilla Association. MMRF has also shepherded the installation of photovoltaic systems in more than a dozen schools (mmrf.bz.org). Like Atitlan Organics then, MMRF has become an important hub of learning and activism around agroecology and permaculture.

\section{Permaculture in El Salvador}

In spite of its proven record as a strategy for achieving agroecological transition on farms large and small permaculture struggles to escape the perception that it is the domain of privileged white folks. Indeed, a survey of 731 permaculture participants in four English speaking countries found that $96 \%$ of respondents were white (Ferguson and Lovell, 2015). Is there a risk then, that permaculture projects in Central America, typically spear-headed by men and women from the Global North, are at odds with larger goals such as food sovereignty and self-determination in the region? While national origins and race may not me problematic in and of themselves, permaculture activists must ask how they can actively prevent permaculture from becoming, in the words of Caradonna and Apffel-Marglin, 'yet another form of well-meaning cultural and ecological imperialism - the Global North trying to "save" the Other by remaking the Other in its own image' (p. 10).

Case studies of permaculture projects in El Salvador by geographer Naomi Millner help to shed light on this question (2016, 2017). Millner has documented the ways that permaculture made its way into post-war El Salvador. Her multi-sited analysis shows the synergies between the farmer-to-farmer agroecology movement and the distinctive approaches of permaculture in small-holding communities. She suggests that permaculture there has helped to revalorize indigenous knowledge by drawing on 'a mixture of research and reimagining, resulting in a hybrid set of practices... Permaculture design techniques are being reappropriated in alignment with indigenous histories and ontologies' in ways that help reclaim 'both biodiversity and the ontological diversity on which that biological 
diversity is based' (Millner, 2016 p. 95-96). In line with Ferguson and Lovell's (2014) argument that permaculture has extended the technical prowess of the agroecological project, Millner's studies suggest that in El Salvador permaculture has also helped to extend agroecology's social and cultural project through popular education practices and leading, in some cases, to greater involvement of women and youth than earlier farmer-to-farmer dialogues had allowed for (Millner, 2017 p. 12).

Permaculture demonstration sites in Central America provide much-needed proving grounds for agroecological methods, both in technical scientific terms and, potentially, in social and political terms. The ability to see, touch and taste the abundance of agroecology is one of the pillars on which an agroecological transition must be built. While experiences remain contingent on a broad range of factors, including the local personal relationships that inevitably characterize collaborations and partnerships, the evidence presented here suggests that permaculture is being deployed ways that can complement the region's long-standing struggles for self-determination and sustainable agricultural development. Still, some potential pitfalls remain which I consider in the concluding section.

\section{Conclusions: Decolonizing Permaculture - Implications for Practitioners and Educators}

While the ability of agroecology and permaculture to meet the goals of productivity, biodiversity, ecosystem services, and ultimately food sovereignty and smallholder resilience are clear, the challenging question of how best to scale up these practices remains (Altieri and Nichols, 2008). As Copeland (2018) has shown in the case of Guatemala, the barriers and complexities of farmer adoption of agroecological techniques are many. Long-standing barriers like landlessness persist for some, while for others it is 'not clear how and with what resources a shift to sustainable agroecology can occur,' (Copeland, 2018 p. 10). Copeland finds evidence that agroecological programs risk resembling the neoliberal and green revolution programs they are intended to replace in the ways they individualize responsibility, and create a sense of voluntarism, whereby reluctant farmers are sometimes critiqued as being lazy and blamed for their own poverty (Copeland, 2018 p.9). Ferguson and Lovell (2014), in their comprehensive review of the permaculture movement, find 'discussions of [permaculture]

120 Revista Geográfica de América Central No 61E (3) Especial CLAG e-ISSN 2215-2563 • Julio-diciembre 2018 • pp. 111-124 
Brian W. Conz. Permaculture demonstration sites in Central America: contributions to agroecological transition and implications for educators

practice consistently understate the complexity, challenges and risk producers face in developing diversified and integrated production systems (p. 251). For these reasons, students of permaculture must be trained to understand the challenges associated with achieving agroecological transition for smallholders in Central America, which, generally speaking, are significantly greater than those confronted by permaculture demonstration site developers from the Global North. A poor understanding of why some smallholders make 'bad' land use choices can reinforce unfair stereotypes of ignorant peasants. If students from Northern Universities come to associate 'good' or sustainable land use with well-meaning expatriates the result is precisely the neo-colonialist outcome cautioned by Caradonna and Appfel-Marglin (2017) cited above.

Caradonna and Apfell-Marglin further argue that "[i]t is legitimate for Western permaculturalists to work with and even assist non-western peoples, but only if permaculturalists are explicitly invited to do so and only if they work with long-established biocultural realities". This helps to draw attention to the fact that the work of permaculturalists from the Global North can closely resemble that of development workers, agricultural extentionists, and missionaries of times past if they carry with them their preordained truths about what sustainability and agroecological transition should look like. Responding to this means taking seriously Altieri and Toledo's (2011) sense that agroecology's emphasis should be on 'the capabilities of local communities to experiment, evaluate and scale-up innovations ...[and] social processes that value community involvement...(p. 588-589). Thus, permaculture practitioners seeking to contribute to food sovereignty and sustainability in Central America and elsewhere in the Global South must avail themselves of the decades of experience and reflection that frameworks like farmer-to-farmer and Farmer First have generated (Holt-Gimenez 2006; Bunch and Scarborough, 1998; Chambers, 1994). In Robert Chambers' words 'Whose criteria and priorities count? Whose knowledge? Whose modes of learning and analysis? Whose tests, experiments, observations, assessments? Whose reality counts?' (Chambers, 1994). If graduates of PDCs in Central America are not trained to ask these questions as part of their work, there is risk that their good intentions for sustainability may negatively impact local communities' goals for food sovereignty and self-determination. 
Finally, these directives have valuable implications for educators who use permaculture demonstration sites as destinations for sustainability education with their students. Citing Mollison and Holmgren's original permaculture work (1978) Ferguson and Lovell (2014: 264) state 'few if any of those [permaculture] techniques originated from within the permaculture milieu. In other words, the local analogues permaculturalists model their sites after are not strictly ecological, but include the experiences and resource use traditions of local smallholders and indigenous peoples (Holmgren, 2002). Permaculture practices are inspired by and adapted from traditional agroecological systems, as in the case of tropical homegardens and the permaculture "food forest"". It is crucial that visits to permaculture demonstration sites be balanced with visits to sites of indigenous small holders. The Q'eqchi Maya, Garifuna and Creole farmers of Belize and the Kaqchikel and other Maya farmers of Guatemala form the matrix of land-based knowledge and experimentation that permaculture sites in Central America take place in, and may see themselves contributing to. While decades of pressure from industrial, green revolution and export-based agriculture have eroded these traditions in many cases, there still exist plentiful examples of on-farm practices, rich in lessons in agroecological practices and strategy. Educating for sustainability and the goal of scaling-up agroecology and permaculture means embracing and understanding this larger context.

\section{Works Cited}

Altieri, M. A. (2018). Agroecology: the science of sustainable agriculture. CRC Press.

Altieri, M. A., \& Nicholls, C. I. (2017). Agroecology: a brief account of its origins and currents of thought in Latin America. Agroecology and Sustainable Food Systems, 41(3-4), 231-237.

Altieri, M. A., \& Toledo, V. M. (2011). The agroecological revolution in Latin America: rescuing nature, ensuring food sovereignty and empowering peasants. Journal of Peasant Studies, 38(3), 587-612.

Bunch, R. (1999). More productivity with fewer external inputs: Central American case studies of agroecological development and their broader implications. Environment, Development and Sustainability, 1(3-4), 219-233. 
Brian W. Conz. Permaculture demonstration sites in Central America: contributions to agroecological transition and implications for educators

Bunch, R., \& Scarborough, V. (1998). People-centered agricultural development: Principles of extension for achieving long-term impact. Lutz E. Agriculture and the environment: Perspectives on sustainable rural development. Washington, DC: World Bank, 145-155.

Caradonna, J. L., \& Apffel-Marglin, F. (2017). The regenerated chacra of the Kichwa-Lamistas: an alternative to permaculture?. AlterNative: An International Journal of Indigenous Peoples, 1177180117740708. Chambers, R. (1994). Foreword in Beyond farmer first: rural people's knowledge, agricultural research and extension practice. Intermediate Technology Publications.

Copeland, N. (2018). Meeting peasants where they are: cultivating agroecological alternatives in neoliberal Guatemala..The Journal of Peasant Studies, 1-22.

Edelman, M., Weis, T., Baviskar, A., Borras Jr, S. M., Holt-Giménez, E., Kandiyoti, D., \& Wolford, W. (2014). Introduction: critical perspectives on food sovereignty. Journal of Peasant Studies, 41(6), 911-931. Ferguson, R. S., \& Lovell, S. T. (2014). Permaculture for agroecology: design, movement, practice, and worldview. A review. Agronomy for Sustainable Development, 34(2), 251-274.

Ferguson, R. S., \& Lovell, S. T. (2015). Grassroots engagement with transition to sustainability: diversity and modes of participation in the international permaculture movement. Ecology and Society, 20(4).

Holt-Giménez, E. (2006). Campesino a campesino: voices from Latin America's farmer to farmer movement for sustainable agriculture. Food First Books.

Holt-Giménez, E., \& Altieri, M. A. (2013). Agroecology, food sovereignty, and the new green revolution. Agroecology and sustainable Food systems, 37(1), 90-102.

Holt-Gimenez, E. \& Patel, R. (2009). Food Rebellions! Crisis and the Hunger for Justice. Food First Books and Pambazuka Press.

Lockyer, J., \& Veteto, J. R. (Eds.). (2013). Environmental anthropology engaging ecotopia: bioregionalism, permaculture, and ecovillages (Vol. 17). Berghahn Books.

Holmgren, D., \& Mollison, B. (1978). Permaculture one. International Tree Crop Institute USA. 
Holmgren, D. (2002). Principles \& pathways beyond sustanability. Holmgren Design Services, Hepburn.

Mathewson, K. (1984). Irrigation horticulture in highland Guatemala: the tablon system of Panajachel. Westview Press.

Millner, N. (2016). Food sovereignty, permaculture and the postcolonial politics of knowledge in El Salvador.Postcolonialism, indigeneity and struggles for food sovereignty: alternative food networks in the subaltern world. London: Routledge, 81-105.

Millner, N. (2017). "The right to food is nature too": food justice and everyday environmental expertise in the Salvadoran permaculture movement. Local Environment, 22(6), 764-783.

Mollison, B. (1988). Permaculture: a designer's manual. Tagari.

Rosset, P. M., Machín Sosa, B., Roque Jaime, A. M., \& Ávila Lozano, D. R. (2011). The Campesino-to-Campesino agroecology movement of ANAP in Cuba: social process methodology in the construction of sustainable peasant agriculture and food sovereignty. The Journal of peasant studies, 38(1), 161-191.

Rosset, P. M., \& Martínez-Torres, M. E. (2012). Rural social movements and agroecology: context, theory, and process. Ecology and society, 17(3).

Taylor Aiken, G. (2017). Permaculture and the social design of nature. Geografiska Annaler: Series B, Human Geography, 99(2), 172-191.

Trauger, A. (2017). We Want Land to Live: Making Political Space for Food Sovereignty (Vol. 33). University of Georgia Press.

Wilken, G. C. (1990). Good farmers: Traditional agricultural resource management in Mexico and Central America. Univ of California Press. 